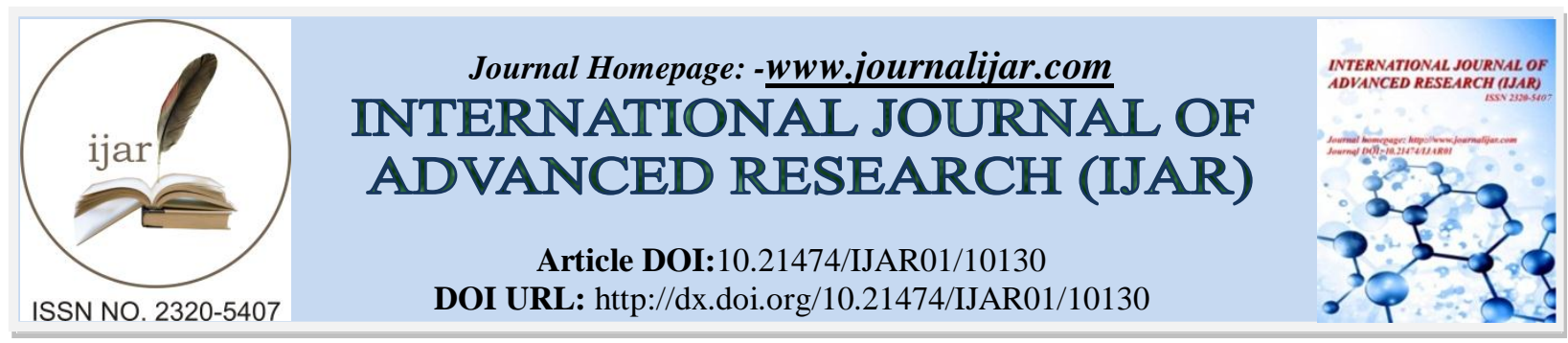

RESEARCH ARTICLE

\title{
DETERMINANTS OF CREDIT DEFAULT OF MICRO FINANCE INSTITUTIONS: CASE OF SHASHEMENE TOWN, ETHIOPIA.
}

\author{
Bogale Boshe. \\ Africa Beza College, department of Accounting and Finance, Hawassa, Ethiopia.
}

\section{Manuscript Info}

Manuscript History

Received: 01 October 2019

Final Accepted: 03 November 2019

Published: December 2019

Key words:-

Shashemene, Loan default,
Abstract

The existing microfinance institutions have tried to bridge the gap of credit accessibility to micro-entrepreneurs but despite this the entrepreneurs or micro-enterprises have been defaulting on their loans. Thus, this study was principally carried out to analyze the factors influencing loan repayment in micro-finance institutions. Descriptive survey was employed with a target population of 30 Loan Officers and 252 registered MFI clients. Stratified proportionate sampling and simple random sampling were employed. Data was collected by use of questionnaires and interviews and analyzed using both descriptive and inferential statistics. Based on Pearson chi-square, the study found that age of respondents, marital status of respondents, education level of respondents and numbers of dependents were individual characteristics that influencing loan repayment performance. In relation to business characteristics those influencing loan repayments were: business type, length or time of operation and number of group members are those variables that significantly predicting loan repayment default. Whereas the lenders characteristics amount of loan was significantly predicting loan default. Therefore, the government and other stakeholders in the sector should ensure that prospective financial borrowers have access to formal education; take in consideration business experience, business type, amount of loan to offer, number of dependents and training on record keeping. The MFI's should adjust the time taken to repay a loan and develop models that are more effective in evaluating credit worthiness of their clients.

Copy Right, IJAR, 2019,. All rights reserved.

\section{Introduction:-}

Microfinance institutions offer medium and small amounts of loans mostly to poor people who cannot afford collaterals to get loans from the main commercial banks. Despite the recent growth in the Micro-finance sector, the sector is faced with challenges of loan repayment defaults by clients. Individual groups have tried using group's equity for collaterals which is expected to ensure the revolving of money for the benefits of other individual's members of the group. However, loan defaults have continued to causes serious challenge to most microfinance institutions. One of the key issues facing the micro finance industry today is the high percentage of loans that are in arrears. In order for micro finance institutions (MFIs) reach scale and move towards operational and financial sustainability, arrears rate must be reduced. High delinquency rates in credit programs for the poor were often

Corresponding Author:- Bogale Boshe.

Address:-Africa Beza College, department of Accounting and Finance, Hawassa, Ethiopia. 
blamed on poor market infrastructure, deficient business income and client's misallocation of loan funds in to consumptions activities (Rural Financial intermediation Program (RUFIP), 2005).

High loan repayment rates benefits both MFIs and the borrowers (Godqin, 2004). Also it is argued that high repayment rates reflect the adequacy of MFIs services to clients' needs. High repayment rate helps to obtain the next higher amount of loan (Bond and Rai, 2009). Contrary to this, if there is low repayment rate, both the borrowers and the MFI were affected. In the case the borrowers will not be able to obtain the next higher loan and the lender will also lose their customer.

As Ahmmed et al. (2012) state, most of the default arose from poor management procedures, loan diversion and unwillingness to repay loans. For this reason, the lenders must give various institutional methods that have targeted to reduce the risk of loan default. However, loan delinquency has continued to causes serious challenge to most microfinance institutions.

This study covered determinants of credit default of Micro Finance institution based on evidence from Shashemene city that are associated with credit default. Studies on credit default are not a new research area. In fact, various researches were conducted in determinants of credit default in different time, but the results of findings were still debatable among different researchers. The finding shows there is inconsistency of result regarding the determinant factor variables. Some variables such as sex, education level, method of lending and loan size have debatable results. Hence, the study tried to fill the gaps by including additional variables on former researchers on determinants of loan default. Besides, as to the researcher's knowledge it appears that no study has been conducted on credit default of Micro Finance institutions in the area. Therefore, this study is aimed to identify the factors that determine credit defaults of MFIs based on evidence from Modjo Shashemene, Oromia Regional State, Ethiopia.

\section{Research Methodology:- \\ Description of the Study Area}

The study was conducted in Shashemene Town of West Arsi Zone, Oromia Regional State. The Shashemene Town distances $260 \mathrm{~km}$ from Addis Ababa, capital city of Ethiopia. From the researcher's own observation and informal discussions with MFIs operators, MFIs in the town have faced numerous challenges which have not been investigated by prior studies

\section{Types and Sources of Data}

In order to meet the objective of the study, the researcher was employed both primary and secondary data. The primary data was collected by face to face interviews using structured questionnaire. Secondary sources include published and unpublished materials about microfinance institution activities.

\section{Sample Size and Sampling Technique}

The study used of simple random sampling because it's the simplest; most convenient and bias free method. The three micro Finance Institutions in Shashemene Town. The target population of this study amounts to 5280 of the clients. Here, the researcher designed to have $95 \%$ confidence level and desire to accept $5 \%$ margin of error.

Finally, the researcher used Taro (Israel 1992). sample size determination formula to determine the sample size of the three micro Finance Intuitions in Shashemene Town. It was calculated as follows

By using the following formula:-

$$
\mathrm{n}=\frac{\mathrm{N}}{1+\mathrm{N}(\mathrm{e})^{2}}
$$

(Israel 1992). Where ' $\mathrm{n}$ ' is the sample size, $\mathrm{N}$ is a total number of population in the Woreda, 'e' is level of precision. Once the total sample size is determined, the sample to be taken from each kebele was allocated proportionately to the number of populations dwelling in each kebeles. In this process, the first sample was selected randomly and the rest were determined by taking every $\mathbf{k}$ unit of observation. Where $\mathrm{K}=\mathrm{N} / \mathrm{n}$. $\mathrm{N}$ is the number of households in each

Kebele and $\mathrm{n}$ is the sample size taken. That is, $n=\frac{5280}{1+5280(0.06137)} 2 \approx 252$

Table 2.1:- List and Sample Appropriation

\begin{tabular}{|l|l|l|l|l|}
\hline S/N & Name of MFIs & Total No. of & Percentage of & Total Number \\
\hline
\end{tabular}




\begin{tabular}{|l|l|l|l|l|}
\hline & \multicolumn{1}{|c|}{ population } & population & of Sample \\
\hline 1 & $\begin{array}{l}\text { Oromia Credit and Saving Share Company } \\
\text { (OCSSCO) }\end{array}$ & 2956 & $61.36 \%$ & 155 \\
\hline 2 & Africa Village Financial Services (AVFS) & 890 & $17.50 \%$ & 44 \\
\hline 3 & $\begin{array}{l}\text { Busa Gonofa Microfinance institutions } \\
(\mathrm{BG})\end{array}$ & 1434 & $21.14 \%$ & 53 \\
\hline Total & 5280 & $100 \%$ & 252 \\
\hline
\end{tabular}

\section{Methods of Data Collection}

The researcher was employed self-administered questionnaires as the data collection instrument. The questionnaires comprises of open-ended and closed-ended questions in order to give the respondents room for airing well thought information adequate to base good judgment. Questionnaires are instruments for data collection that are defined to elicit written respondents from the subject in the study.

\section{Data Analysis and Presentation}

Descriptive statistics method was applied to analyze quantitative data where data was scored by calculating the percentages, mean, standard deviation and Variance. SPSS was used to generate tabulated reports, charts, and plots of distributions and trends, as well as generate descriptive statistics and more complex statistical analyses. Inferential statistics were applied through the use of inferential statistical test analysis to establish the nature of the existing relationship between the dependent and independent of the research variables.

\section{Result And Discussion:-}

individual/Client's Characteristics

Table 3.1:- Client characteristics

\begin{tabular}{|c|c|c|c|}
\hline Sr. No. & Variables & Category & Percent \\
\hline \multirow[b]{2}{*}{1} & \multirow[b]{2}{*}{ Sex of Respondents } & Male & $55.2 \%$ \\
\hline & & Female & $47.5 \%$ \\
\hline \multirow{4}{*}{2} & \multirow{4}{*}{ Age of Respondents } & $18-30$ & $40.5 \%$ \\
\hline & & $31-40$ & $30.3 \%$ \\
\hline & & $41-50$ & $21.1 \%$ \\
\hline & & Above 50 & $8.1 \%$ \\
\hline \multirow{4}{*}{3} & \multirow{4}{*}{ Level of Education } & Primary school & $9.76 \%$ \\
\hline & & Secondary school & $62.93 \%$ \\
\hline & & College level & $47.71 \%$ \\
\hline & & University & 0.0 \\
\hline \multirow{4}{*}{4} & \multirow{4}{*}{ Marital Status of Respondents } & Single & $32 \%$ \\
\hline & & Married & $53 \%$ \\
\hline & & Divorced & $9 \%$ \\
\hline & & Widow/Widower & $6 \%$ \\
\hline \multirow[t]{3}{*}{5} & \multirow{3}{*}{ No. of Family or dependent } & $1-2$ & $50 \%$ \\
\hline & & $3-5$ & $52.3 \%$ \\
\hline & & $6-10$ & $61.5 \%$ \\
\hline \multirow{4}{*}{6} & \multirow{4}{*}{ Occupation of borrowers } & Agriculture & $83.3 \%$ \\
\hline & & Business & $12.5 \%$ \\
\hline & & Technical work & $0.9 \%$ \\
\hline & & Permanent work & $3.2 \%$ \\
\hline
\end{tabular}

Sources:- Survey Result (2017)

The client's characteristics consisted of sex, age, level of education marital status and number of dependents. With respect to sex of clients, of the male respondents $(55.2 \%)$ were defaulted in payments while $(47.5 \%)$ of the females 
were defaulted. This result shows that there is a good enthusiasm for females to take loans from micro-finance institution. However, this result shows that there was no significant difference in loan repayment default between males and females.

With regarding to age structure of respondents, table 3.1. Above displayed the borrowers' age category and credit default quantitative variables. The result indicates that people of different age categories borrow loans from micro finance institution. When age was analyzed it was found that $8.1 \%$ of the respondent who were aged above 50 years defaulted in loan repayment, $21.1 \%$ aged between 41 and 50 years defaulted, 30.3\% aged between 31 and 40 defaulted in loan repayment, and $40.5 \%$ aged between 18 and 30 defaulted. This implies that those aged between $18-$ 30 years comprise a huge proportion of loan defaulters of MFI. This indicates that young people were more likely to default than the old counterpart. This is almost certainly; because young borrowers have more pressure with their lives hence they might allocate loans in more risk activities for expecting high returns.

When marital status of respondents' effects were analyzed, the study found out that, in relation to loan repayment default, 32 percent of the defaulters among respondents were single, 53 percent were married defaulted, 9 percent of respondents divorced defaulted and finally 6 percent representing widows/widowers defaulted. This indicates that married respondents or clients were likely to default and followed by unmarried clients. In contrary to this divorced and widows/Widower clients were less defaulted in loan repayment than married and single clients counterparts.

When number of families' or dependents' effects were analyzed it was found that among respondents assisting 1-2 persons $50.0 \%$ of them were defaulted, among those supporting 3-5 persons $52.3 \%$ of them were defaulted and among those supporting 6-10 persons $61.5 \%$ of them were defaulted. This indicates that respondents supporting many families or many dependents were likely to default than those supporting fewer families/dependents.

When the year of schooling of borrowers' effects were analyzed in relation to loan repayment default, the study found out that, $9.76 \%$ of those with primary level education were defaulted, $62.93 \%$ of those with secondary level of education were defaulted, $47.71 \%$ of those with college level education were defaulted and $0.0 \%$ of those with university level education were defaulted. The result shows that, all people of different education levels took or borrowed loans from micro-finance institution. This implies that, there is no education level segregation when micro finance institution issue loans. The education information reflects the real education status of the respondents. This demonstrates that, loan repayment default cases were low among people with post-secondary education as compared to those who had unto secondary level of education.Possessing of a primary education is a key to borrowers for enabling them to make simple investment analysis. Hence, it might help the borrowers to allocate their loans well and ultimately reduce the probability of loans default. The study further reveals that, the borrowers with secondary education lead to default their loans followed by college borrowers and primary level. This is probably because secondary education borrowers have more pressure with their lives. Hence, they might allocate loans in more risk activities for expecting high returns. Implying that lending to borrowers with secondary education is more risky than others counterparts. However, risk could be reduced by relevant risk mitigation techniques.

When occupations of borrowers' were analyzed against credit default it was found that $83.3 \%$ of the main occupation of borrowers was agriculture. However, $12.5 \%, 3.2 \%$ and $0.9 \%$ of the borrowers' main occupation were business, permanent employment and technical work respectively. The results show that majority of the borrowers engaged in agricultural activities hence large amount of loans were subjected to risk of default since majority of borrowers were involved in uncertain (agriculture) activity. Hence, it is conclusive that agriculture is seasonal and it depends on rain fed.

As clearly seen on Table 3.1 above majority of borrowers i.e. $58 \%$ of them spent their loans in agricultural activities which is a risky activity because majority of farmers in Shashemene depends on rain fed agriculture.

Lender's Characteristics

Table 2.3:- lender's characteristics

\begin{tabular}{|l|l|l|l|}
\hline Sr. No. & Variables & Category & Percent \\
\hline \multirow{3}{*}{1.} & \multirow{4}{*}{ Loan size } & Br. 3000-6000 & \\
\cline { 3 - 4 } & & Br. 6000-35000 & \\
\cline { 3 - 4 } & & Br. 35000-100000 & \\
\hline
\end{tabular}




\begin{tabular}{|c|c|c|c|}
\hline \multirow[t]{3}{*}{2.} & \multirow{3}{*}{ Types of collateral } & Land plots and house & $85 \%$ \\
\hline & & Livestock & $7 \%$ \\
\hline & & Others & $8 \%$ \\
\hline \multirow[t]{5}{*}{3.} & \multirow{5}{*}{ High Interest rate } & Agree & $81.5 \%$ \\
\hline & & Strongly agree & - \\
\hline & & Neutral & - \\
\hline & & Disagree & 15.1 \\
\hline & & Strongly disagree & 3.4 \\
\hline \multirow[t]{3}{*}{4.} & \multirow{3}{*}{ Repayment period } & $1-3$ month & $21 \%$ \\
\hline & & 3-12 months & $43.7 \%$ \\
\hline & & 18 months & $35.3 \%$ \\
\hline \multirow[t]{5}{*}{5.} & \multirow{5}{*}{ Poor Record keeping } & Agree & $68.9 \%$ \\
\hline & & Strongly agree & $3.4 \%$ \\
\hline & & Neutral & $4.2 \%$ \\
\hline & & Disagree & $22.7 \%$ \\
\hline & & Strongly disagree & $0.8 \%$ \\
\hline
\end{tabular}

Sources:- Survey Result (2017)

With regarding to the loan duration and credit default, the loan duration was 1 to 18 and 3 to 18 months for borrowers. The study finds that all financial institutions issued 1-3 months loan for their members to cover emergence events such as health problems, paying the school fees or funeral were $21 \%$. Most of the micro finance issued 3-12 months loans for social, business and agricultural activities were $43.7 \%$ while 18 months loans were targeted for house and business premises building or maintenance were $35.3 \%$.

Regarding with amount of loan and credit default, the results found that the amount of loans received by borrowers ranges from birr 3,000 to 100,000 . The results shows that the maximum loan for credit default was a bit larger compared with that of the borrowers with minimum loan. Thus, the larger the sizes of loan the more the risk of credit default. This result is consistent with Moti et al (2012) who reveal that the risk of credit default increases with the increase of the amount of loans received by borrowers' in. in line with, Vuuren (2011) reveals that the size of loan influences the repayment performance.

Concerning interest rate charged by lender institution, almost more than half of the respondents which accounts about 68.9 percent were agreed with the unfair interest rate charged by lender financial institution ( i.e., they confirmed that, the presence of high interest rate charged by lender institution) in the area. Only a few respondents, 22.7 percent were disagreed with this problem and 3.4 percent, 4.2 percent and 0.8 percent of respondents showed as strongly agree, undecided and strongly disagree respectively on the issue. Accordingly, the dominance of the sampled respondents, were complained the high interest rate charged by lender institution. Which mean, interest rate of the loan which ranges from 12 percent to 18 percent, is not reasonable for such emerging and young enterprises, which are not economically strong and invest large proportion of money they borrow on large infrastructures.

In concerning record keeping and documentation, as viewed in table 3.2, out of the total sampled, 81.5 percent of borrowers agreed as they have poor record keeping and documentation in their enterprises, contrary to this, only 15.1 percent of them disagreed with the presence of poor record keeping and documentation in their enterprises. About 3.4 percent of the respondents strongly agreed with the existence of poor record keeping and documentation in their firm. The largest percentage of respondents' response demonstrated that most of the enterprises had no properly recorded and documented data in their enterprise. Because of the existence of poor record keeping and documentation, most of the enterprises fail to repay their loan appropriately.

With respecting to types of collateral, the results indicate that $85 \%, 7 \%$ and $8 \%$ of borrowers used land plots and house, livestock and others means as their collateral respectively. Other means of collateral includes furniture, borrowers' savings and deposits and guarantors' assets. The results shows that majority of borrowers used their land plots and house as their collateral. However, this practice poses various challenges to the micro finance institution. First, it is very difficult to sell a house of borrowers to pay the loans during the event of default because this seems as against humanity. Since selling the house affects both spouse and children in the households. Also some married 
couples did not involve their partners to seek mutual agreement in using house as collateral during the loan processing. Therefore, spouse could pose obstacle to sell the house at an event of loan default emphasizing the house belongs to the whole family. Also most of the houses in the rural areas lack legal valuation or deeds, making it difficult to attract the high prices during the loans default. This implies the borrower who mentioned house or land plots as their collateral had high risks of default than others.

\section{Inferential Analysis:-}

Inferential statistical analysis was used to investigate the factors influencing loan repayment problem among borrowers in microfinance institutions in Shashemene town. The Pearson chi-square test was used.

Table 3.3:- Likelihood Tests

\begin{tabular}{|l|l|l|l|}
\hline \multirow{2}{*}{ Variables } & Likelihood/ Relationship Test & \multicolumn{2}{l|}{} \\
\cline { 2 - 4 } & Chi-square & Df & .712 \\
\hline Age & .136 & 1 & .000 \\
\hline Marital status & 55.969 & 3 & .000 \\
\hline Dependents & 69.607 & 3 & .000 \\
\hline Education & 19.519 & 2 & .001 \\
\hline Business type & 16.313 & 3 & .002 \\
\hline Time in Business & 15.026 & 3 & .000 \\
\hline No. of group borrowers & 47.117 & 3 & .000 \\
\hline Loan activity & 32.418 & 3 & .125 \\
\hline Repayment duration & 2.348 & 1 & .161 \\
\hline Loan size & 1.965 & 1 & .000 \\
\hline Collateral & 24.549 & 3 & .157 \\
\hline
\end{tabular}

Sources: Survey Result (2017)

As undoubtedly depicted on the above table 3.3, with respecting to individual characteristics, the significant positive sign on the sex variable indicated that the likelihood of a loan repayment problem was higher for males than for females' counterparts. In conclusion, as Pearson chi-square test result in the table above reveals explicitly that sex of the respondent was not an important or significant predictor of loan repayment default despite the fact that age of respondents, marital status of respondents, number of dependants/families and education levels of the respondents were useful parameters or significant in the prediction of loan repayment default. As a result, there is a significant difference on the credit repayment default in relation to the difference in the age, marital status, number of dependents and educational status of respondents. Therefore, based on the above statistical test result, age of respondents, marital status of respondents, family or dependent number and educational level can be considered as factors affecting the loan repayment performance.

In relation to business characteristics, how long a business has been in operation, types of business, loan activity and numbers of group members were tested to examine the relationship or likelihood between the dependent and independent variables. Accordingly, the Pearson chi-square result revealed that the business type variable was positive and significant at the 5\% level of significance. This implied that borrowers involved in agriculture, such as farming and animal husbandry, were more likely to have a problem repaying the microcredit loan than borrowers involved in a small business activity. The dependence of agriculture on the weather conditions caused fluctuations in production that were beyond the control of the farmers. Hence, since borrowers involved in agricultural activities have a greater problem repaying their loan, Microfinance institutions need to consider giving flexibility in loan repayments to borrowers who receive income irregularly caused by drought or flood. In line to this, the number of group borrowers and the type of the business run appear to be useful parameters in the prediction of loan default. On the other hand, loan activities seem not to be useful parameters in the prediction of default.

In regard to lender characteristics, how long loan repayment or loan duration is given, how the worth of a customer is evaluated and consideration for collateral seem not to be useful parameters in the prediction of loan default by group members since these parameters have significance levels above 0.05 . As a result, these variables were not 
considered as a significant predictor of credit default in this study result. In contrary to this, amount of loan given to borrowers were given the impression of being a significant predictor of loan defaulter in the study area. Therefore, the Pearson chi-square $\left(\mathrm{X}^{2}\right)$ result suggested that, there is statistically an association between the loan size difference or amount of loan difference and credit default. In conclusion, the result suggested that amount of loan difference have an important effect on credit repayment problem.

\section{Conclusion and Recommendations:-}

The existing microfinance institutions have tried to bridge the gap of credit accessibility to micro-entrepreneurs but despite this the entrepreneurs or micro-enterprises have been defaulting on their loans. Thus, this study was principally carried out to analyze the factors influencing loan repayment in micro-finance institutions. Descriptive survey was employed with a target population of 30 Loan Officers and 252 registered MFI clients. Stratified proportionate sampling and simple random sampling were employed. Data was collected by use of questionnaires and interviews and analyzed using both descriptive and inferential statistics. Based on Pearson chi-square, the study found that age of respondents, marital status of respondents, education level of respondents and numbers of dependents were individual characteristics that influencing loan repayment performance. In relation to business characteristics those influencing loan repayments were: business type, length or time of operation and number of group members are those variables that significantly predicting loan repayment default. Whereas the lenders characteristics amount of loan was significantly predicting loan default

\section{Recommendations:-}

The following are recommended to control or minimize default.

The credit supervisor should check with credit officers daily to ensure that policies are followed and the supervisor must respond quickly to solve credit officers' problems. It makes no sense to have strong policies on paper that are not followed in the field. Next, if credit officers have a specific geographic region, they can visit clients more often; limiting geographic scope, reduces time and money wasted traveling from the office to clients' businesses. More visits enable credit officers to develop relationships in their neighborhoods'. Management and credit officers need to pay attention to details. The average arrears rate of each credit officer's portfolio should be tracked weekly or biweekly. Credit o fficers must respond quickly to problem clients in their portfolios.

Another strategy for reducing arrears is to loan only to micro entrepreneurs who have been in business for at least twelve months. Businesses are most likely to fail within the first year of operation so if they have existed for at least twelve months on the owner's money, the infusion of money from the MFI should be at a lower risk than if the business is a start-up.

Yet another way to reduce arrears/default is for MFIs to require the credit officer to visit the client and the client to receive training prior to the disbursement of each loan. It is easy for MFIs to assume that a client or group should get larger loans after each loan cycle, assuming that clients will repay new loans on time if they have repaid past loans on time. However, it is often on the second and third loans that clients fall behind, perhaps because the loan size has grown too big or because the client has begun to take the MFI for granted. The MFI should apply the same rigorous financial and character tests to both new and repeat loans.

Finally the government and hence bank of Shashemene should also regularly monitor and supervise the MFIs so as to ensure safety of clients' deposits and customers' confidence.

\section{Reference:-}

1. Ameyaw-Amankwah, I. (2011). Causes and effects of loan defaults on the profitability of Okomfo Anokye Rural Bank.

2. Anbes, T. (2003). Pattern of credit use and its impact on small farmers' income: A study in Dire Dewa area, Eastern Ethiopia. (Unpublished M.Sc. thesis). Alemaya University, Ethiopia .

3. Basu, A., Blavy, R., \& Yulek, M. (2004). Microfinance in Africa: Experience and lessons from selected African countries. IMF Working Paper .

4. Canadian International Development . (2007). Supporting the Development of Inclusive Financial Systems. Micro Finance Guidelines . 
5. Creswell, J. W. (2003). Research Design: Qualitative, Quantitative and Mixed Methods Approaches (2nd ed.). California: Sage Publications.

6. Getachew, T. (2006). Integrating financial services into the poverty reduction strategy, in Ethiopia.

7. Ghatak, M., \& Gunnane, T. (1999). The Economics of Lending With Joint Liability: Theory and Practice. Journal of Development Economics .

8. Hans, D. S. (2005). Does History Matter? The Old and the New World of Microfinance in Europe and Asia", October 2005, Cologne. University of Cologne Development Research Center .

9. Jemal, A. (2003). Microfinance and Loan Repayment Performance: A Case Study of The Oromia Credit an Savings Share Company (OCSSCO) in Kuyu. Msc Thesis, Addis Ababa University, Addis Ababa .

10. Joanna, L. w. (2013). A Financial Market System Perspective: The New Microfinance Handbook. Washington, DC: World Bank.

11. Ledgerwood, J. (1999). Sustainable Banking with the Poor, Microfinance Handbook, the Institutional and Financial Perspective. The World Bank: Washington D.C.

12. Meron, M. (2008). Loan Provision, Degree of Collectability and Reason For Default: A Case Study in Wise Saving and Credit Cooperatives Union for Women. Msc Thesis, Addis Ababa University, Addis Ababa.

13. Monir, A., Serajul, I., \& Mohammad, T. R. (2012). Analysis of Repayment Behavior In Banks Customer Perspective. Case of Bangladeshi Mercantile Limited Bank. World Review of Business Research , 2 (6).

14. Muhammad, Y. (1999). "Banker to the Poor", Micro-Lending and The Battle Against World Poverty, New York, Public Affairs.

15. Nelson, V. (2003). Microfinance In Times of Crisis: The Effect of Competition, Rising Indebtedness, and Economic Crisis on Repayment Behavior. World Development.

16. Oladeebo, J. O., \& Oladeebo, O. E. (2008). Determinants of loan repayment among smallholder farmers in Ogbomosho agricultural zone of Oyo state, Nigeria. Social Sciences Journal , 17 (1), 59-62.

17. Paur, T. (2006). Design of a new micro leasing product for the East African market (Diploma thesis). Nairobi, Kenya.

18. Samuel, S. A. (2011). Credit default risk and its determinants of microfinance industry in Ethiopia (Master thesis). Addis Abeba University.

19. Sengupta, R., \& Aubuchon, C. P. (2008). The Microfinance Revolution: An overview. Federal Reserve Bank of st. Louis review , 90 (1), 9-30.

20. Sheila, A. L. (2011). Lending Methodologies and loan losses and default in a Microfinance deposit-taking institutions in Uganda. A case study of Finca Uganda Kabala Branch (MDI). Research report presented to Makerere University, Uganda .

21. Triodos, F. (2013). Policy Review and Private Sectors Development: Country Report of Ethiopia,January 2013, Netherlands.

22. Warue, B. N. (2012). Factors affecting loan delinquency in Microfinance in Kenya. International Journal of Management Sciences and Business Research , 1 (12).

23. Warue, B. N. (2012). Factors affecting loan delinquency in Microfinance in Kenya. International Journal of Management Sciences and Business Research , 1 (2).

24. Wolday, A. (2000). Review of Microfinance Industry in Ethiopia: Regulatory Framework and Performance. AEMFI, Occasional. 